\title{
The Asymmetric Warfare Environment as Described by the Participants
}

\author{
Giuseppe Caforio *
}

\section{Introduction}

The completion of a cross-national research study on a sizeable sample of military personnel who had participated in asymmetric warfare operations has resulted in a variety and breadth of survey material that is deserving of further examination. ${ }^{1}$ Additional study of the data gathered in this research is particularly important in order to recon-

Giuseppe Caforio is retired general of the Italian Army. He is past president of the Research Committee 01 "Armed Forces and Conflict Resolution" of the International Sociological Association (for 12 years), vice-president of the Italian Interuniversity Centre of Historical and Military Studies, founding member and coordinator of a working group of the ERGOMAS, as well as member of several other institutes of research. He is too an outside consultant of the governmental Italian Centre of Strategic and Military Studies. He has a Strategic Sciences degree, a Law degree, a Political Science degree, a Master in Communication Science. He has authored or co-edited over 160 scientific publications (books, articles in journals, chapters in joint monographs, etc.) on various sociological, political science and methodology issues at an international level in Bulgarian, Chinese, Dutch, English, French, German, Italians, Russian, Slovenian and Spanish. The research study described in this article was conducted jointly by the Research Committee 01 of the International Sociological Association and by the Working Group on the Military Profession of the European Research Group on Military and Society (ERGOMAS). The report drawn from the research is in the course of publication with the title "Soldiers without Frontiers: The Experiences from the Ground."

1 "Asymmetric warfare" describes a conflict that pits a weaker side against a stronger adversary, and from the use of war-fighting techniques that are vastly different from the traditional ones that enable the weaker side to stand up to its stronger adversary. For more research on this subject see, among others, Matt Armstrong, The Art of Asymmetric Warfare, a blog on public diplomacy and strategic communication in the twenty-first century (28 July 2008); Roger W. Barnett, Asymmetrical Warfare: Today's Challenge to U.S. Military Power (Washington, D.C.: Brassey's, 2003); Giuseppe Caforio, "The Asymmetric Warfare: In Search of a Symmetry," in Armed Forces and Conflict Resolution: Sociological Perspectives, ed. Giuseppe Caforio, Bandara Puarkayastha, and Gerhard Kümmel (Bingley, U.K.: Emerald Group, 2008), 7-23; Caforio, "Officer and Commander in Asymmetric Warfare Operations," Journal of Defense Resources Management (April 2013); Th.A. Van Baarda and D.E.M. Verweij, The Moral Dimension of Asymmetrical Warfare: Counter-Terrorism, Democratic Values and Military Ethics (Leiden: Martinus Nijhoff Publisher, 2009); and Alise Weibull and Bengt Abrahamsson, eds., The Heritage and the Present: From Invasion Defence to Mission Oriented Organisation (Karlstad: Swedish National Defence College, 2008). 
struct the environment of this type of warfare, with special regard to the human impact of such conflicts on the participants. ${ }^{2}$

This closer look is possible because of the way in which the research was conducted, by means of in-depth, semi-structured interviews, which gave the interviewees a chance to go beyond the topics strictly pertaining to the interview's structure and to talk more expansively about their lived experiences, emotions, and backgrounds. The richness of this data will be rendered in this essay through direct quotation of the interviewees' responses, preserving their vivacity and, at times, simplicity, and limiting the comments of the article's author to a minimum.

The essay deals with four aspects of asymmetric conflict: its nature as seen by the participating soldiers, their relations with the other actors present in the theatre of operations, their assessment of how the soldiers to be sent on a given mission were selected and prepared, and the particular experiences gained in the theatre.

\section{The Nature of Asymmetric Conflict}

The first topic that is examined here is the nature itself of asymmetric conflict, as it appears in the testimonies of the protagonists, in its dual aspect of war-fighting on the one hand and civil action on the other. In many instances, this latter aspect of the work took on the de facto nature of civil replacement; soldiers were asked to carry out tasks and functions that in that particular territory at that particular moment were not being performed by the civilian authorities who were normally responsible for them. It is well known and amply discussed in the literature on this subject (see footnote 1) that one of the chief (and contradictory) characteristics of asymmetric warfare is precisely the mingling of these two aspects and their constant intersection. This characteristic also poses one of the greatest difficulties to the service personnel involved - that is, the necessity of being able to pass at any moment from the role of the social worker to that of the combatant, and back again.

We have gathered abundant data on both of these aspects. Indeed, if we consider, by way of example, the current conflict (now in its eleventh year) in Afghanistan, I believe that there can be no doubt with regard to its characterization as a war. This statement is borne out by the number of dead and wounded, the use of war munitions (quantitatively and qualitatively), the type of means deployed, and the combat situations that have occurred. And, as a war, it is a particularly insidious one, due to the mingling of the insurgents with the civilian population and their use of guerrilla techniques and terrorism. These qualities of the Afghanistan conflict are amply recorded in the experiences of the soldiers participating in the ISAF coalition. And the same applies to combat experiences in other theatres that have received less media coverage but that have been equally characterized by episodes of asymmetric warfare, such as Africa, the Middle East, the Balkans, etc.

2 The theatres in which the interviewed soldiers chiefly had their experiences were: Central Africa, Afghanistan, the Balkans, Iraq, Lebanon, the Persian Gulf, and the Philippines. 
Participants experienced the asymmetric conflict environment as a true war theatre and this fact is reported by numerous testimonies, such as:

I was involved in a big fire fight on June 11, 2009 and appreciated how my mates reacted to the fire. I was in command of an armored craft ("Lince"): my machine gunner was wounded on his arm, but he remained at his post. The craft behind me was heavily hit (two casualties) and a pickup truck carrying Afghan soldiers was blown up by an IED: I talked with them few minutes before, and was hit particularly hard by their death (Italian NCO, deployed in Afghanistan).

In Sudan, I experienced more attacks of guerrilla groups towards the peacekeepers. These groups are the ones who are supporting the government, and they were specializing in attacking tribes, peacekeepers, car-jacking and kidnapping (South African soldier).

When I was assigned in Mindanao, the combat operations were brutal. In Cotabato, in one instance, my fellow soldier was killed after he went to fetch water (Filipino sergeant).

I've been under fire in Somalia ... But otherwise it's probably Afghanistan that has made the greatest impression on me in connection with IEDs (Danish soldier).

We have fired warning shots, both with the cannon on the ship, during a hijacking of a big ship, and our helicopter also fired warning shots with a TMG [heavy machine gun]. The same applies for the FRØ'ere (special forces) with which we sailed, they also fired warning shots. We have also blown their ships up (where I participated) (Danish sailor).

I took part in fire fights as a Mangusta [helicopter] pilot. Our job was to provide force protection to army units. Once a big truck column, escorted by Afghan and Spanish units, fell into an ambush in a very narrow valley and was hit by intensive fire; they asked for our support, and we intervened with two Mangusta and searched for and engaged insurgents, firing rockets and shooting at them with a small-caliber gun for an hour and a half" (Italian pilot, in Afghanistan).

Given the frequency and intensity of these encounters, the sense of relief felt by participants when armed clashes did not take place is consequently high, as related by a Slovenian soldier: "No combat operations, but we were prepared if something would happen. Sometimes it's kind of the dream that doesn't come true - you are being trained for a hard job, but at the end of the day you don't get what you wanted. On the other hand, when you think that you may die, it's good that we weren't engaged in a difficult situation, and that we all survived...."

This raises the fact that asymmetrical warfare is a very particular type of warfare, because it takes place in the midst of civilian populations from whom the insurgents are frequently indistinguishable. In such settings, every activity carried out by military units affects the lives and attitudes of these populations, a fact that is testified to by reports like the following one, relating to an action carried out by a Canadian unit: ${ }^{3}$

3 See Sean M. Maloney, "Incursion at Howz-e Madad: An Afghanistan Vignette," Canadian Military History 17:1 (2008): 13. 


\section{THE QUARTERLY JOURNAL}

When Canadian forces built a combat road (Route SUMMIT) from Bazaar-e Panjwayi to Highway 1, there were unintended consequences. The construction of this road diverted water in the east end of Zharey. Age-old and intricate tribal agreements over water use were now disrupted. Certain communities now had the potential upper hand over others, and resentments built up bordering on violence. A Canadian solution was to put in culverts to restore the water use patterns - but the culverts made ideal locations for IED (improvised explosive device) attacks against forces using Route SUMMIT. When culverts were blown up, was this Taliban activity or not? If one community resorted to AK-47 use over a diverted stream, was this Taliban action? What if Canadian troops were caught in the crossfire? Or, what if Afghan police from one area were conducting activities on behalf of someone else for pay because they had not received monies from their own chain of command for months? These factors complicated any Canadian response to activity in Zharey District.

Many of our interviewees provided similar testimony that attested to the difficulty of being involved in confusing conflict situations in very close quarters: "In one engagement, I hesitated for a moment because the rebel was a female. I shot her anyhow at ten meters range" (Filipino soldier, Philippines). Or, as a South African solider deployed in Sudan described his experience: "It was a bit scary, but shocking at the same time, because I saw almost everyone on the streets were armed, so I could not see the difference between armed forces and civilians."

A fundamental characteristic of asymmetric conflict (and the origin of its complexity) is the mixing of combat operations with a series of activities that are aimed at improving the living conditions, mobility, and education of the local population. This characteristic, summarized in the imperative "to win the hearts and minds" of the local population, was abundantly illustrated in the interviews that we conducted. ${ }^{4}$

We are peacemakers. We did school construction, medical and dental missions, circumcision, joined in their events/parties, worked on the construction of roads and public information campaigns (Filipino official, Philippines).

Well, I had direct contact because I taught. Alongside Base España there was a school. It is a small school attended by children from the nearby town, from seven to twelve years old. I have been teaching them. I had an interpreter, and I taught gymnastics (Spanish NCO, Lebanon).

Our main activities are non-combat in nature, mostly civil-military operations (Filipino soldier, Philippines).

We may have to perform missions of a very different nature, more humanitarian and quite logical and reasonable (Spanish soldier, Afghanistan).

I worked as head of a cell working on civil-military cooperation [CIMIC]. Civil-military cooperation is very important, because it is a tool in the hands of the commander to make the environment friendly and to complete the mission in an easier way (Italian officer, Afghanistan).

4 See David H. Petraeus, "Learning Counterinsurgency: Observations from Soldiering in Iraq," Military Review (January/February 2006): 2-12. 
I gained experiences in working in a very different environment than at home, and experience with mentoring (Slovenian NCO, Afghanistan).

The two functions that troops are asked to carry out in asymmetric conflicts-military and civilian - are often intertwined: "Together with the local police we carried out territory control, convoy escort, but particularly territory control. Besides, I distributed humanitarian aid," an Italian soldier reported. His Spanish counterpart stated: "We had to perform missions of a different nature, more humanitarian, but in Afghanistan you come to see how suitable our training is. Fortunately or unfortunately, we have to use on the ground what we have learned in our training." And a Spanish officer said of a commander: "He stresses that the concept of civil-military cooperation is becoming a core concept in Afghanistan."

In summary, with regard to what is asked of the individual soldier in an asymmetric warfare environment, one must conclude with Mario Renna that "the modern soldier must know how to fight, but also how to prevent and persuade, understand about explosives but also about building schools, he has to know how to speak in public and to address listeners who are sometimes hostile or mistrustful...."5

\section{The Different Actors Present in the Theatre}

The soldiers deployed on asymmetric warfare missions found themselves interacting with numerous other actors in the theatre. The most significant interactions that left the strongest mark in the memories of the interviewees were those with the personnel of other armies that participated in the mission (consider that in Afghanistan, for example, the coalition was made up of forces from forty-two different countries), those with the local population, and those with the insurgents.

\section{Relations Between Soldiers}

The relationships and comparisons with the soldiers of other armies appear to be particularly significant in the recordings of the interviews, above all for the aspect of comparison between one's own organization/institution and that of one's partners. Added to this is the aspect of national and cultural differences, which are cast into high relief through the daily interactions on joint deployments.

With respect to the first aspect, the primary comparison is generally made to U.S. troops, who were deemed by most of the interviewees to be the most professionally advanced and therefore most worth measuring up to. A Bulgarian soldier relates, for example: "Because I used to work with colleagues from the U.S. Army, my experience is mainly with them. Originally they seemed haughty and dismissive, but once they were convinced of the quality of the Bulgarian military, they totally changed their mind." Concerns with being up to standard and being perceived as such stand out here.

5 Mario Renna, Ring Road, sei mesi con gli Alpini in Afghanistan (Milan: Mursia Editore, 2011), 83 . 
Paying closer attention to the U.S. forces also led some soldiers to note what they considered to be defects in U.S. performance and attitude, in particular forms of arrogance in relation to the other military contingents:

Power differentials are one of the major differences among different cultures, but it was not difficult to adapt. Most of the military personnel were U.S. in NTM-A HQ. So, U.S. folks were conducting daily life as if it was a pure U.S. HQ. They were doing some ceremonies according to U.S. traditions, since they were the majority. I respected their rituals. But in a multinational environment, there must be a multinational culture and daily life. I don't have to celebrate U.S. holidays, and I don't have to eat meals on a dining table covered by a U.S. flag (Turkish officer, Afghanistan).

Since we are in a foreign country with the aim of bringing them peace, those local people and local army personnel deserve respect from our cultural point of view. But this is completely different for some other countries, especially Americans. British soldiers pay more attention to this, but American soldiers do not consider what the opposing person might feel. For example, an American NCO may chew an Afghan general out for not bringing enough ammunition for a live fire training (I witnessed this event). I went to the general and asked why he let him behave like that. The answer was sad, because he said that he received his salary from that NCO. The British at least refer to those local officers that are of higher rank as "sir." When I asked a British NCO about this difference, he said, "Americans still have a long way to go. We had some experience in the past. We also have a long way to go, but we are ahead of the Americans" (Turkish officer, Afghanistan).

In other cases, it is the concrete comparison, especially on the level of logistical organization, that takes center stage: "I felt that logistical support for soldiers in the U.S. military was enormous (e.g., support facilities such as gyms, swimming pools, PX, mess halls, etc., and programs for leisure time through voluntary participation). On the contrary, I felt that support in our case is insufficient, and leisure time programs sometimes appeared as a burden, like an obligation or daily routine (Korean soldier, Afghanistan).

It is a comparison that also extends to other coalition armies, however, according to individual experiences, as a Bulgarian NCO observed:

In Afghanistan, I was at the base of the British Army, in which the only thing you had to think of was how to perform your duties. For everything else was taken care of:

1. Laundry: British washing machines - you went, left your clothes, and the next morning they are washed and prepared, with perfume sprayed on.

2. Food: The base has four canteens. You have the right to eat where you like. The food was varied, at least five types of different food in each dining room.

3. Free U.S. Internet: You can talk thirty minutes a day - enough for everyone.

4. Three sports halls: Only if you have time and desire for sports.

5. Five different shops: Whatever you needed, it was there.

6. Five pubs: If you like to drink coffee, cola, it was all there.

We also received specific remarks in relation to the contingents of other countries: 
During KFOR 22 we were in the French camp. It was strange. They were arrogant, and unable to speak a foreign language. They disliked speaking English. In the canteen, we sat at each our tables: Moroccans, Slovenes, Germans, Swedes, etc. (Danish soldier, Balkans).

We (the Danes) had just moved, so I missed the kitchen. We've gone from 300-400 to 200 men in the French camp. But it worked well enough. There was the problem that the French did not speak English - until after ten beers. Confidence was OK. ... There were also the Moroccans who had the guard service. They were weird. Many of them had been there for three years. They returned home just before the rotation, and could then have time to assemble the next batch. They were weird; they did not speak English, but French (Danish soldier, Balkans).

U.S. soldiers are kind, and they generally praise their colleagues and subordinates and try to solve problems for their team members. The Italian soldiers, they are fun but do very little. Female soldiers think, Italian guys are attractive and try to get together with these guys.

I and other non-native foreign officers had some difficulties understanding New Zealand and Australian officers. My best friends are from the countries that are near to the Mediterranean Sea-Italy, Spain, Portugal, Greece, etc. We were very close with Greek officers especially.

French officers always tried to say some words at the start of every meeting. I think that they intended to show that they had important opinions on every subject and that they affected coalition decisions (Turkish officer, Afghanistan).

But there are also those who expressed negative judgments on their relations with the soldiers of the other countries with whom they came into contact, such as this South African NCO (in DRC): "With respect to soldiers from other countries, jealousy exists. They hate the RSA with a passion. Especially the Indians and Bangladeshis. They send RSA troops to the red zone and then to green zones. When an RSA soldier is reported for a minor case, they are quick to judge and report us to the UN. Whereas I know of a situation in which Guatemalan troops were caught red-handed sleeping with local women, and nothing was done to them. They just hate the presence of RSA troops in the DRC."

\section{Relations with Local Populations}

The contact of soldiers from developed countries with the local populations of less culturally and economically developed countries (which are those where asymmetrictype conflicts have tended to arise) generally leads to feelings of compassion regarding the poor living conditions of these populations and of dismay at the local situation.

I never thought and expected people to live in such terrible living conditions as they are living in Afghanistan (Slovenian soldier).

I was shocked by the damage and the harsh conditions of the country. You get to see many problems, a suffering society and the hatred they feel one another. It is very different from our comfort in the Western countries. You arrive to a very different place. You notice you have to help them improving their living conditions (Spanish NCO, Afghanistan). 


\section{THE QUARTERLY JOURNAL}

When arriving in Afghanistan for the first time I thought I arrived at the end of the world. Everything was very dirty. Afghanistan is one big garbage dump (Slovenian soldier).

I find out that there are people who are suffering, somebody can kill your family member, and no case will be opened, because he is in power with his group. They can take anything, no matter what you have, without any permission. Thank God we are South Africans. Hunger is their daily meal (South African soldier deployed in Sudan).

The experience of racial conflict is striking: "In terms of the local population, it was interesting that the Tutsi got on very well with the white officers - they are the minority. The Hutus were less friendly. All the interpreters were Tutsi, and this was problematic as they hate the Hutus. 'They can teach South African's something about racial hatred' - was the comment" (South African officer, Rwanda).

There was also a commonly expressed sentiment that the local population took an exploitative attitude toward the peacekeepers:

The local population definitely saw the opportunity to exploit the RSA soldiers to the maximum. We utilized their local knowledge and rewarded them accordingly. But nothing you got was for free. Social, sport, etc. interactions always had a price you had to pay. Unfortunately our soldiers exploited their poverty status by exploiting their ladies (South African officer, DRC).

People accept all soldiers as invaders regardless of their national classification. They just want to get some benefit like money or food from you. This is the way most of people behave toward us (Turkish officer, Afghanistan).

Among the soldiers on a mission, an attempt at comprehension toward the local populations was prevalent. Many soldiers discussed efforts to understand local customs, language, and culture: "The relation between us and the DRC people - for me it was good, because I always wanted to know how are they living and I even taught myself the language so that I could understand them better. I'm just not happy with the way they live. They work like slaves, especially females and children, and it seems like men are the most relaxed people there. Most people don't have jobs, some don't even have places to stay" (South African officer, DRC). This attempt at understanding was facilitated in some cases by cultural and/or religious affinity: "Local people had the same culture like Turkish people, so that Afghan people and Turkish officers were able to understand each other easily. Also, religion was an important factor in establishing a good relationship with local people" (Turkish officer, Afghanistan).

There is no lack of curious episodes in the relations between very different cultures, like the one reported by a Bulgarian officer: "There was a rumor spread among the locals that when we use sun glasses, we can see them naked. Many of them believed it. When I realized this, I gave my glasses to the interpreter to see me 'naked,' and that was how I broke this myth."

\section{Relations with Insurgents}

Relations with the insurgents are lived for the most part as relations with phantasms, with an invisible enemy. In most cases the interviewees had not actually seen the insur- 
gents. An IED, whether identified or exploded; a hit-and-run attack on a column of vehicles; a hail of mortar and rocket fire; the fear of reprisals and the hostility of village chiefs - these are the manifestations of the insurgents with which most of the soldiers we interviewed came into contact. If we examine the individual interviews, we can glean experiences of this type of spectral relationship:

There were bullets coming 'from nowhere' (Bulgarian soldier, Afghanistan).

Attacks often come from the villages, and you don't know where and against whom to fire, because we were very careful not to hit civilians (Italian officer, Afghanistan).

In some instances I have experienced pursuing enemies that seem to just disappear. This is an indication that they indeed have local protectors (Filipino NCO, Philippines).

Definitely there were women and children combatants (Filipino NCO).

Yes, it is difficult because they only shoot without observing who are they shooting, and some are not in uniform (South African soldier, Sudan).

However, there are exceptions that are worth citing:

The so called 'guerrillas' or 'soldiers' are mostly economically motivated criminal gangs. They do not fight ideological wars, although the gang leaders become politicians to further their economic aims. In essence they are just criminals (South African soldier, DRC).

I have to tell you my personal story. In one engagement, I hesitated for a moment because the rebel was a female. I shot her anyhow at ten meters range. It turned out that she was a former student at UP Cebu; she was called 'doctor' by the communist group because she was a medic (Filipino officer, Philippines).

The rebels were dressed exactly like the Sudan forces and they ordered us to stop (South African soldier, Sudan).

A Spanish officer even evaluated the insurgents' combat abilities. He contrasts "the will to die for their cause of the Taliban with the reluctance of the Afghan Army to take control of the military operations and stability efforts."

A separate discussion must address the experiences of sailors, who, in the fight against piracy, have in many cases had direct experience with the pirates they are working to stop. An Italian sailor, for example, reported: "In these occasions we had human contact with people from very different origins and typologies. Few pirates are really from Somaliland: most of them come from Yemen, Pakistan, India too. The Somalis normally stay on the 'mother boat,' a fishing boat from which small and speedy motorboats depart to board merchant ships." Another sailor commented, "I was impressed by the pirates' mood: they have a way of thinking very different from us. To be a pirate is like another job, according to them." A third sailor described the pirates' fighting methods: "The pirates usually had mother ships, which were fishing boats, with which they captured small craft of fisherman or others (especially Yemenites), sometimes killing them, sometimes setting them adrift on a small boat. The fishing boats were also procured in this manner." 


\section{THE QUARTERLY JOURNAL}

This is not solely an Italian experience. A Danish sailor reported, for example: "We have not been under fire, but one day we had to stop a pirate boat. The helicopter was in the air, and we had to stop the boat, but they would not stop, so we fired warning shots, but they did not stop until the sniper fired a warning shot into the top of the hull. Then it really occurred to me what it was we were dealing with. They were totally unaffected that we had fired on them, and that gives you a good impression of what kind of people they are." A South Korean midshipman also encountered pirates at first hand: "I had an opportunity to observe closely a suspected pirate vessel, to recognize the behavior of pirates towards combat vessels, and to gain know-how of the confrontation operations of suspected pirate vessels."

In short, the experience of the insurgents appears to be well illustrated by what Mario Renna writes (in relation to Afghanistan): "To describe the members of these groups [of insurgents] newspapers and television often simplify, speaking generically about "Taliban"; a strong image that evokes not only a military but also an ideological adversary. The reality is much more fragmented, however: in fact, national security forces and NATO patrols are attacked by criminal bands, opium smugglers and hired, more or less anti-Western irregular militias." 6

\section{Selection and Training of Personnel}

The concrete experience of operations in asymmetric warfare environments puts the training that soldiers have received beforehand under severe scrutiny, as well as the process of selecting the personnel to go on these missions. The interviewees from all of the countries represented in our study appear to be particularly critical with regard to personnel selection. For example, among the Bulgarian officers interviewed, affirmations of the following type were recorded:

The selection of officers should be extremely thorough and designed to meet international requirements.

I suggest ... to select people very carefully; it is unacceptable to send officers to occupy positions for which they have not been trained - for example, sending a staff officer to a position in the intelligence cell of the division.

We should work to end the selection of people to participate in a mission on the basis of 'connections' (informal and friendly relations), and to improve the selection of people based on open and transparent criteria.

With regard to training, general military training for conventional combat was typically considered to be sufficient; however, the various challenges of asymmetric warfare were held to require more specific forms of preparation. A South African officer stated, for example: "I think more training in the asymmetric field would have assisted me in handling the situation. Conventional war is simple and straightforward. My training was definitely inadequate for the task I was given, and that goes for everyone

6 Mario Renna, Ring Road, sei mesi con gli Alpini in Afghanistan (Milan: Mursia Editore, 2011), 13. 
who was under my command. More emphasis during training should be placed on irregular or asymmetric warfare. Our unit should focus on asymmetrical warfare training and put members on similar smaller operations or simulations to gain experience and exposure during training. There must be panic inducing situations."

Preparation for commanders that centered on supplementation and sharing the experiences that their predecessors had on the ground was also felt to be important, in addition to more practice in the English language, as a Bulgarian officer pointed out: "There must be interactions between people who have occupied a position in a past mission and people who are about to hold that position. There must be more detailed information about the environment in which someone is going to work (for both military camps and the area of operation). Language skills have to meet the modern NATO standard. Additional language training, including professional terms, acronyms, conversational skills, etc., should be developed. Local pilots were required to fly under the rules of ICAO and NATO, which are written entirely in English, but it was very difficult for them, and there were many misunderstandings, especially when they were talking to Americans and Englishmen."

Sharing the experiences of those who preceded them in the theatre is something that many of the interviewees called for. As one Korean soldier said, "In order to enhance the level of pre-deployment training, we may have to transfer certain types of knowledge from experienced personnel, and the unit in charge of deployment has to prepare for deployment more systematically. One of his comrades noted: "Since we were deployed as the first contingent to Afghanistan, plenty of time was needed for preparation. During the period of preparation, the U.S. and Australian military personnel who had experience there came and gave us a great deal of help."

This transfer of previous knowledge was especially valuable because, as a Slovenian soldier said: "Everything is different, different climate, way of work. You cannot train enough at home if we don't have weather that reaches 50 degrees." Preparation aimed at replicating the peculiar characteristics of asymmetric warfare was felt to be particularly essential, because, as a South African officer stated: "We were trained in terms of what to do when under fire, not how to negotiate, how to deal with accidents, how to handle opposing forces when weapons were drawn but not fired." Another South African officer added: "Yes, there is a need for better training in people skills, negotiation skills and cultural awareness. We definitely need more social workers on these operations." Because the characteristics of good training for the asymmetric environment are peculiar, as another soldier pointed out, "They also educated us on how to calm somebody to get their trust and to win the mind and heart of the local population."

Basically, for the great majority of the interviewees, training for conventional combat is necessary, and was well provided to the soldiers making up the sample, but it must be supplemented with specific training in other aspects of asymmetric warfare, training that in various cases is deemed deficient. The soldier to send on asymmetric warfare missions, in order to be well prepared as a soldier, must definitively also acquire preparation as a social worker, negotiator, arbiter, and expert in civil-military cooperation. 


\section{The Experiences Gained}

Whatever assessment one wishes to give of participation in asymmetric warfare missions, it involves a series of experiences that leave their mark on the soldier's entire life, both professional and non-professional. This is clearly asserted by all of the interviewees who, nearly unanimously, consider having participated in such missions a positive experience. For our purposes here, rather than make a detailed examination (such as in percentage terms) of the enrichment that having participated in operations of this type brought to individuals, it seems more interesting and in the spirit of this article to report in the interviewees' own words a series of personal lived experiences, both negative and positive, each with its particularities.

The former are obviously more numerous than the latter, as these people experienced a war environment where frustrations can be frequent, as appears in the following testimonies:

There was also a night we were going down to look at a merchant ship that maybe had been hijacked. It turned out that it was hijacked, and when they saw us as daylight came, they began to threaten the crew on board and called us up on the radio and threatened to harm the crew, so we sailed away again. You feel a tremendous frustration at not being able to help these poor people who have been hijacked (Danish sailor, Persian Gulf).

I saw while we were driving a rebel group open fire at three young women, killing two and injuring the other; you feel helpless, because I only had one armed escort, and we could not risk being two and having to go against a gang (South African soldier, Sudan).

Much more particular is the macabre experience reported by a Danish major during his activity in the Balkans:

Exchanges of corpses (from my diary). I'll have to tell you about corpses and what these can be used for here during the war and how they can be kept. Corpses are a commodity! Better than money, which means that the individual manager within his area of responsibility buries the corpses of the enemy at approximately $60 \mathrm{~cm}$ depth. This, after he has wrapped the bodies in plastic or whatever is at hand. It can, as I saw in several cases, be plastic from packages of oranges. If a single chief loses terrain, he is forced to dig up the corpses and move them to another area because dead bodies, as I said, are a commodity. The bodies can be used as a means of payment (exchange) for corpses of one's own men, or as payment for food. Depending on what it is you want to get in exchange, it must be made through negotiations. This was my biggest task in Bihac, to attend these meetings, ensuring that security was in order and to ensure that the agreements were respected to the letter, which means that I often helped to dig up the bodies and then load these on to our own trucks, and not least to make sure that it was the right number of corpses. I will not dwell on all these exchanges, however I will mention a few in particular which made an impression on me.

On 28 May 1995, the Bosnian foreign minister, Irfan Ljubijankic, was shot down by rebel Serbs near Bihac. He was shot down along with three other cabinet members of the Bosnian Serbs when his helicopter was on its way to a meeting.

After some initial meetings in Licko Petrovo Selo, it was finally decided that on June 7 an exchange of corpses would take place between Serbs and Muslims regarding the four persons who had been shot down on 28 May. I've never participated in some- 
thing similar. The Muslims came with thirty-nine corpses and three POWs. We usually carry around eight corpses on our trucks; the Muslims had no military truck, so they had piled the thirty-nine corpses on a small truck, which meant they had to crawl on top of dead bodies to get them out. Some of the corpses were no longer able to hang together. When the bodies were finally unloaded, a process was started to piece together some of the corpses. Some corpses were missing a leg, an arm, a hand, a foot. And, not to repeat myself, the corpses were not transported in any kind of coffins, but in plastic of any kind - it was a particularly macabre job. Naturally problems arose when the other party felt or found that there were missing parts of the corpses. Besides those of us who were usually attending these exchanges, there was at this exchange almost half the world's press, who naturally were all photographing. All in all, an ugly experience.

Another painful experience, again in Bosnia, recalled the atrocity of the extermination camps of World War II, here with regard to the exchange of prisoners:

A few days later the Serbs handed over eighteen prisoners of war who had been in a POW camp for eight to twelve months. The actual transfer took place without any problems, but it must have been an incredible experience for those who were transferred, and it must have felt like winning the lottery. We've all seen films of concentration camps from the Second World War and how people were treated, the emptiness of their eyes visible to everyone. That was it for me when these POWs came limping, stumbling, on crutches over to a life they thought they would never experience again. Never have I seen greater emptiness than in those eyes of those people who until they stood with their arms around their loved ones did not think that they would experience this again.

The interviewees often witnessed disturbing moments, like that one reported by a Spanish sailor in the waters off Sarajevo: "When I got really shocked was during Christmas of 1994. I was a rookie, and I remember being on the aircraft deck, which now is prohibited, and asking a companion about the lights I saw from the boat. I thought they were celebrating the feasts, but it was Sarajevo being bombarded."

But the interviewees' experiences were not uniformly negative. The positive experiences that were reported were those in which the soldier, whose mission is always one of peace, can see that the action undertaken and completed has managed to change the local situation. We will offer few examples in this vein:

It was nice to see the kids go to schools established by the ISAF, see them play ball outside schools. Seeing the population (some) get better, women in women's centers, etc. (Danish soldier, Afghanistan).

A good experience was - at the end of the mission - to go to a village and find an open air market, people wearing party clothes, walking and trading: a normal situation, very different in respect to the first time I went to the same village, when it seemed like a ghost town (Italian soldier, Afghanistan).

Once the local population warned us that some rockets had been placed to be used against us; they indicated the site, and we proceeded in destroying them. Another time we organized a shura, which 250 heads of villages took part in. We had the opportunity to explain our work, our intentions, etc. The result was very positive, and allowed us to better understand the Afghan reality (Italian officer, Afghanistan). 


\section{THE QUARTERLY JOURNAL}

Operation Green Angel, a civil-military operation, was planned to spend two to three weeks repairing villages that had poor living conditions, and once the work was done, we got together to play with the village people. We really enjoyed getting acquainted with them. Through working together for two to three weeks, we became closer by talking about life here and there (Korean soldier, Afghanistan).

The satisfactions achieved in terms of personal and professional enrichment appear to be both important and widespread:

I personally gained a lifetime's experience which I will never forget. It was fun, scary, and sad. Your bond with your fellow mates got stronger and protective over each other; you form a family (South African soldier, DRC).

I am very satisfied. I work a lot more professionally now. I have learned to say No and to ask for help when it became too stressful. I've developed a great deal, both personally and professionally. I have matured and grown, and have gained a different outlook on my life after seeing people's conditions in Africa; I am not just taking things for granted anymore. You see how well off you really are. I've also learned to work with my colleagues in a completely different way after we've been through these episodes where something happens with pirates. You learn to communicate in a different way during stressful situations, etc. (Danish officer, Persian Gulf).

\section{Conclusion}

As I have already had occasion to note in another essay, ${ }^{7}$ for militaries at all levels, operating in an asymmetric warfare environment means being prepared to act "in the presence of civilians, against civilians, in defense of civilians where civilians are the targets, objectives to be won, as much as an opposing force." 8 It means forgetting some fundamental principles of combat, and accepting the use of minimal force, and even that only when strictly necessary. It means that leaders need to acquire the ability to motivate themselves and their men, and to apply these limitations, in the process accepting greater personal risk. It means being able to assume governance roles in local settings that have very different cultures, norms, and customs from those of one's home country. It means being prepared to manage a multiplicity of functions simultaneously, not all of them military. It means acquiring interoperability with military contingents of nations that are very different from one's own. It means having to expand one's professional toolkit into sectors and disciplines that are far removed from one's education

7 Giuseppe Caforio, "Officer and Commander in Asymmetric Warfare Operations," Journal of Defense Resources Management 1 (2013): 9-26.

8 Bengt Abrahamsson, "Restraint, Unbridled Emotion and War Amongst the People," in The Heritage and the Present: From Invasion Defence to Mission Oriented Organisation, ed. Alise Weibull and Bengt Abrahamsson (Karlstad: Swedish National Defence College, 2008), 147-68. 
and training. ${ }^{9}$ It means all this and even more which, from time to time and from mission to mission, proves to be important and necessary.

The essay presented here has dealt with four aspects of asymmetric conflict from the point of view of the participating military personnel: its nature, the relations between the different actors in the theatre, the training received, and the particular experiences lived. This has been done by reporting the words of soldiers who took part in missions in asymmetric warfare environments. It is a procedure that may perhaps have done harm to an organic treatment of the individual topics addressed, but that made it possible to preserve the liveliness and spontaneity of the expressions. The reader is thus left with the task (and the pleasure) of extrapolating the recounted experiences and linking and connecting them with each other in order to form a personal framework of comprehension of the examined environment.

9 Ebbe Blomgren, "Is Military Praxis in International Missions Reforming the Profession?" in The Heritage and the Present: From Invasion Defence to Mission Oriented Organisation, ed. Alise Weibull and Bengt Abrahamsson (Karlstad: Swedish National Defence College, 2008), 233-42; Giuseppe Caforio, ed., The Flexible Officer: Professional Education and Military Operations Other Than War, A Cross-National Analysis (Gaeta: Artistic \& Publishing Company, 2001). 


\section{Bibliography}

Abrahamsson, Bengt. "Restraint, Unbridled Emotion and War Amongst the People." In The Heritage and the Present: From Invasion Defence to Mission Oriented Organisation, 147-68. Karlstad: Swedish National Defence College, 2008.

Barnett, Roger W.. Asymmetrical Warfare: Today's Challenge to U.S. Military Power. Washington, D.C.: Brassey's, 2003.

Blomgren, Ebbe. "Is Military Praxis in International Missions Reforming the Profession?" In The Heritage and the Present: From Invasion Defence to Mission Oriented Organisation, 233-42. Karlstad: Swedish National Defence College, 2008.

Caforio, Giuseppe. "Officer and Commander in Asymmetric Warfare Operations." Journal of Defense Resources Management (2013).

Caforio, Giuseppe. "The Asymmetric Warfare: In Search of a Symmetry." In Armed Forces and Conflict Resolution: Sociological Perspectives. Bingley, U.K.: Emerald Group Publishing, 2008.

Caforio, Giuseppe. The Flexible Officer: Professional Education and Military Operations Other Than War, A Cross-National Analysis. Gaeta: Artistic \& Publishing Company, 2001.

Maloney, Sean M.. "Incursion at Howz-e Madad: An Afghanistan Vignette." Canadian Military History 17, no. 1 (2008).

Petraeus, David H.. "Learning Counterinsurgency: Observations from Soldiering in Iraq." Military Review (2006): 2-12.

Renna, Mario. Ring Road, sei mesi con gli Alpini in Afghanistan. Milan: Mursia Editore, 2011.

Van Baarda, Th.A., and D.E.M. Verweij. The Moral Dimension of Asymmetrical Warfare: Counter-Terrorism, Democratic Values and Military Ethics. Leiden: Martinus Nijhoff Publisher, 2009.

Weibull, Alise, and Bengt Abrahamsson. The Heritage and the Present: From Invasion Defence to Mission Oriented Organisation. Karlstad: Swedish National Defence College, 2008. 